\title{
PENGARUH PENERAPAN MODEL PEMBELAJARAN INKUIRI TERHADAP HASIL BELAJAR TENTANG SISTEM GERAK
}

\section{THE EFFECT OF INQUIRY LEARNING MODEL TOWARDS LEARNING ACHIEVEMENT AT THE TOPIC DISCUSSION OF MOTION SYSTEM}

\author{
Baiq Nely Widya Anggraini, Syachruddin AR, dan Agus Ramdani \\ Program Studi Pendidikan Biologi FKIP Universitas Mataram, Mataram, Indonesia \\ Email: nelywidyaa@gmail.com, dinar_bima@yahoo.co.id, aramdani07@unram.ac.id
}

Diterima : 14 Februari 2019. Disetujui : 2 Maret 2019. Dipublikasikan: 9 Januari 2020

\begin{abstract}
Abstrak. Penelitian ini bertujuan untuk mengetahui pengaruh penerapan model pembelajaran inkuiri terhadap hasil belajar tentang sistem gerak pada peserta didik kelas VIII di SMP Negeri 1 Mataram tahun 2018. Jenis penelitian ini adalah quasi experiment dengan desain nonequivalent control group design. Populasi dalam penelitian ini yaitu seluruh peserta didik kelas VIII di SMP Negeri 1 Mataram tahun 2018 yang terdiri dari 11 kelas. Sampel ditentukan dengan menggunakan teknik simple random sampling sehingga terpilih kelas VIII A sebagai kelas kontrol dan VIII B sebagai kelas eksperimen. Instrumen yang digunakan dalam penelitian yaitu tes objektif untuk mengukur hasil belajar peserta didik. Analisis data menggunakan uji t. Data yang diperoleh menunjukkan bahwa hasil belajar peserta didik kelas eksperimen meningkat sebesar 36,6 (dari 33,4 ke 70) sedangkan hasil belajar kelas kontrol meningkat sebesar 30,7 (dari 29,25 ke 59,95). Analisis data pada skor capaian menunjukkan $t_{\text {hitung }}$ lebih besar dibanding $t_{\text {tabel }}(2,05>1,99)$. Hal ini disebabkan karena model inkuiri memberikan peserta didik kesempatan untuk menemukan masalah, mencari jawaban dan menyimpulkannya, peserta didik belajar dengan memanfaatkan lingkungannya, dan bekerja sesuai prosedur ilmiah. Hasil analisis terhadap nilai capaian menunjukkan adanya perbedaan hasil belajar pada kelas yang menggunakan inkuiri dengan yang tidak. Berdasarkan hasil tersebut dapat disimpulkan bahwa terdapat pengaruh signifikan dari penerapan model pembelajaran inkuiri terhadap hasil belajar tentang sistem gerak pada peserta didik kelas VIII di SMP Negeri 1 Mataram tahun 2018.
\end{abstract}

Kata Kunci: Inkuiri, Hasil Belajar, Sistem Gerak

\begin{abstract}
The purpose of this research is to know the effect of inquiry learning model towards learning achievement of $8^{\text {th }}$ grade of student at the topic discussion of motion system in SMPN 1 Mataram in 2018. This research belongs to quasi experiment. The research was conducted by the nonequivalent control group design. The research population was all 11 classes of $8^{\text {th }}$ grade students in SMPN 1 Mataram. Class VIII-A (as a control) and VIII-B (as an experiment) were established by using simple random sampling technique. The data were collected by using an objective test. The data analysis technique was t-test. The result showed that the learning achievement of experiment class increased 36,6 (from 33,4 to 70) while the control class's learning achievement increased 30,7 (from 29,25 to 59,95). Gain score analysis with t-test showed that $t_{v a l u e}>t_{\text {table }}(2,05$ $>1,99)$. This is because the inquiry learning gives students th eopportunity to identify queation, find answers and conclude it, students learn by utilizing their environment, and work according to scientific procedures. Analysis result with the gain score showed the different learning achievement between the class that using inquiry model of teaching and control class. Based on the research result it can be concluded that inquiry learning model has a possitive effect towards learning achievement of $8^{\text {th }}$ grade student at the topic discussion of motion system in SMPN 1 Mataram in 2018.
\end{abstract}

Keywords: Inquiry, Learning Achievement, Motion System

\section{PENDAHULUAN}

Salah satu hal yang menjadi penekanan dalam kurikulum 2013 adalah peserta didik berperan aktif dalam membangun pengetahuannya (student center). Pembelajaran seharusnya tidak lagi berpusat pada penjelasan-penjelasan pendidik, dengan kata lain dalam hal ini pendidik bertindak sebagai fasilitator bagi peserta didik dalam mengembangkan pengetahuannya. Kurikulum 2013 juga menuntut pendidik untuk mengembangkan pengalaman belajar yang optimal sehingga peserta didik mampu untuk membangun pengetahuannya.
Sistem gerak merupakan salah satu pokok bahasan yang terdapat pada kompetensi dasar di kelas VIII. Kriteria ketuntansan minimal (KKM) yang ditetapkan untuk mata pelajaran IPA di SMP Negeri 1 Mataram adalah 75. Berdasarkan hasil pengamatan selama PPL periode I dari bulan Agustus hingga Desember 2017 di SMPN 1 Mataram, hasil belajar peserta didik pada materi sistem gerak masih banyak yang belum mencapai KKM yang ditentukan oleh sekolah. Rata-rata hasil ulangan harian peserta didik pada materi sistem gerak hanya mencapai nilai 68,88 . Selain itu, 
terdapat beberapa konsep yang masih belum dikuasai siswa yakni pada konsep gerak pada benda dan sendi manusia.

Kegiatan belajar mengajar tidak lagi sekedar menyampaikan dan menerima informasi, tetapi mengolah informasi sebagai masukan pada usaha peningkatan kemampuan [1]. Seiring dengan perkembangan teknologi dan ilmu pengetahuan, pendidik tidak bisa hanya mengandalkan penjelasan dalam menyampaikan materi kepada peserta didik, yang dibutuhkan adalah peningkatan kemampuan peserta didik untuk memperoleh dan mengolah informasi yang ditemukannya.

Pendidik di SMP Negeri 1 Mataram sudah menerapkan kurikulum 2013 dalam pembelajaran, akan tetapi masih terdapat beberapa hal yang belum sesuai. Dalam penerapan kurikulum 2013, pendidik cenderung membiarkan peserta didik belajar sendiri tanpa memberikan arahan, sehingga peserta didik bingung dalam mengumpulkan dan mengolah informasi yang ada. Peserta didik lebih banyak menghafal kata-kata yang diperoleh dari buku dan tidak memahami maksud dari konsep yang mereka dapatkan. Peserta didik juga belum bisa menerapkan metode saintifik yang dituntut dalam kurikulum 2013 karena belum mendapat arahan yang jelas dari pendidik terkait masalah yang harus dicari oleh peserta didik. Hal ini menyebabkan hasil belajar peserta didik rendah dan belum memenuhi KKM yang ditetapkan untuk pelajaran IPA khususnya sistem gerak

Model inkuiri atau disebut juga scientific inquiry adalah sebuah model pembelajaran yang dirancang untuk memberikan pengalaman kepada peserta didik dengan menggunakan metode saintifik. Inkuiri (inquiry-based teaching) adalah suatu strategi yang berpusat pada peserta didik (studentcentered strategy) yang menuntun peserta didik untuk mencari jawaban terhadap pertanyaanpertanyaan dengan mengikuti suatu prosedur yang digariskan secara jelas [2].

Inkuiri merupakan pendekatan mengajar yang berusaha meletakkan dasar dan mengembangkan cara berpikir ilmiah. Pendekatan ini menempatkan peserta didik lebih banyak belajar sendiri, mengembangkan kreatifitas dalam pemecahan masalah [3]. Kegiatan pembelajaran dalam pembelajaran berbasis inkuiri ditujukan untuk menumbuhkan kemampuan peserta didik dalam menggunakan keterampilan proses yang ditandai dengan merumuskan hipotesis, melaksanakan percobaan, mengumpulkan dan mengolah data, mengevaluasi dan mengkomunikasikan hasil temuannya dalam masyarakat belajar [4].

Model pembelajaran inkuiri baik untuk diterapkan guna meningkatkan hasil belajar peserta didik [5-6]. Penelitian lainnya juga menunjukkan bahwa model pembelajaran inkuiri jika dibandingkan dengan model pembelajaran konvensional lebih efektif dalam meningkatkan prestasi belajar peserta didik pada suatu unit pengajaran [7]

Pembelajaran inkuiri dirancang dengan tujuan mengembangkan peserta didik agar memiliki kemampuan ilmiah, dan juga memotivasi melakukan keterlibatan langsung dalam proses pembelajaran. Inkuiri memberikan peserta didik pengalaman-pengalaman belajar nyata dan aktif [8]. Model inkuiri dapat meningkatkan hasil belajar peserta didik karena dapat merangsang minat dan perhatian peserta didik untuk belajar, sehingga peserta didik mampu belajar secara aktif dalam kelompok dan belajar dengan menyenangkan melalui benda-benda abstrak yang mampu dilihat peserta didik [9].

Berdasarkan uraian di atas, peneliti merasa perlu untuk melakukan penelitian dengan judul: "Pengaruh Penerapan Model Pembelajaran Inkuiri Terhadap Hasil Belajar Tentang Sistem Gerak pada Peserta didik Kelas VIII di SMP Negeri 1 Mataram Tahun 2018".

\section{METODOLOGI}

Penelitian dilaksanakan pada pembelajaran semester ganjil tahun ajaran 2018/2019. Pengambillan data dilaksanakan dari bulan Juli sampai September 2018. Adapun tempat penelitian yaitu di SMP Negeri 1 Mataram.

Jenis penelitian yang digunakan dalam penelitian ini yaitu quasi experimental research atau eksperimen semu dengan pendekatan kuantitatif deskriptif. Desain penelitian yang digunakan dalam penelitian ini adalah nonequivalent control group design.

Populasi dalam penelitian ini adalah seluruh peserta didik kelas VIII di SMP Negeri 1 Mataram yang terdiri dari 11 kelas yaitu VIII A sampai VIII K. Teknik pengambilan sampel yang digunakan dalam penelitian ini yaitu simple random sampling. Sehingga diperoleh kelas VIII-A sebagai kelas kontrol dan kelas VIII-B sebagai kelas eksperimen.

Instrumen yang digunakan dalam penelitian in adalah tes hasil belajar dalam bentuk tes objektif yang berjumlah 35 soal yang telah divalidasi oleh ajli dan validasi empiris. Data hasil belajar yang terdiri dari nilai pre-test dan post-test dianalisis dengan menggunakan uji-t.

\section{HASIL DAN PEMBAHASAN}

Perbandingan pre-test dan post-test hasil belajar peserta didik pada kelas kontrol dan eksperimen dapat dilihat pada Gambar 1.

Berdasarkan data tersebut, hasil pada pre-test kelas kontrol diperoleh rata-rata 29,25 sedangkan kelas eksperimen memperoleh rata-rata 33,40. Hasil post-test pada kelas kontrol dan eksperimen diperoleh nilai yang berbeda. Kelas kontrol memperoleh rata-rata 59,95 , sementara pada kelas eksperimen diperoleh rata-rata 70 . 
Analisis skor capaian peserta didik dengan menggunakan uji $\mathrm{t}$ diperoleh hasil bahwa $t_{\text {hitung }}$ lebih besar dibanding $t_{\text {tabel }}(2,05>1,99)$, sehingga $\mathrm{H}_{0}$ ditolak dan $\mathrm{H}_{\mathrm{a}}$ diterima. Hal tersebut menunjukkan bahwa terdapat pengaruh signifikan dari penerapan model pembelajaran inkuiri terhadap hasil belajar tentang sistem gerak pada peserta didik kelas VIII di SMP Negeri 1 Mataram tahun 2018. Berdasarkan hasil tersebut diketahui bahwa terdapat pengaruh dari penerapan model pembelajaran inkuiri terhadap hasil belajar tentang sistem gerak pada peserta didik kelas VIII di SMP Negeri 1 Mataram tahun 2018. Hal ini sejalan dengan hasil penelitian sebelumnya
[6, 10-13]. Selain itu, sebagai data penunjang dilakukan pula uji regresi sederhana dengan hasil koefisien determinasi sebesar 0,11. Hal tersebut menunjukkan terdapat pengaruh penerapan model pembelajaran inkuiri pada kelas eksperimen sebesar $11 \%$.

Berdasarkan rata-rata skor capaian peserta didik, diperoleh rata-rata yang berbeda signifikan antara kelas kontrol dengan kelas eksperimen. Nilai peserta didik pada kelas eksperimen juga memperoleh rata-rata yang lebih tinggi. Hal tersebut dapat dilihat pada Tabel 1 .

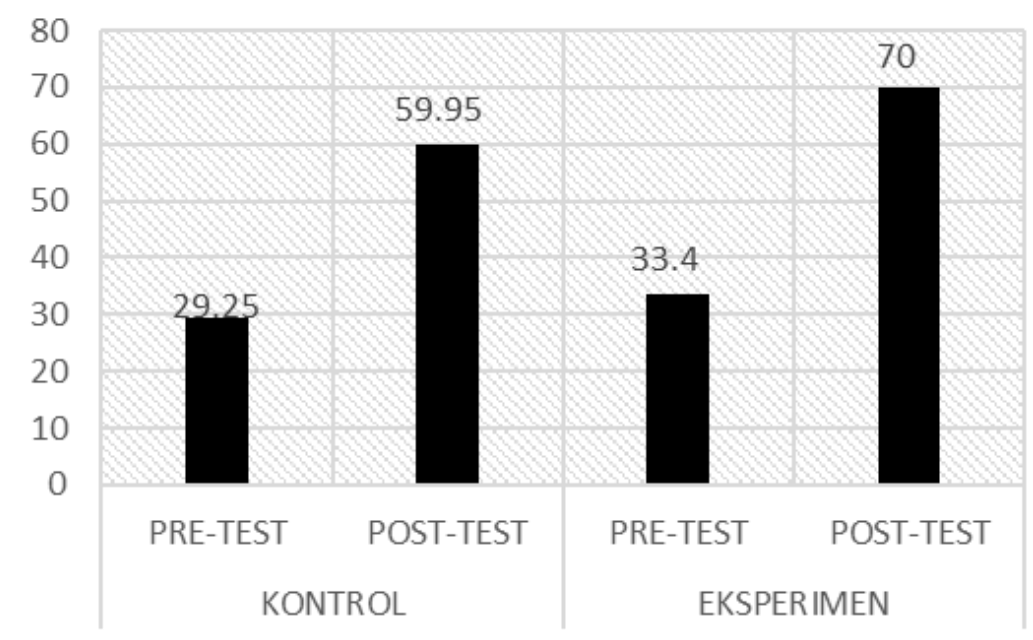

Gambar 1 Deskripsi perbandingan pre-test dan post-test pada hasil belajar peserta didik di kelas kontrol dan eksperimen

Tabel 1 Deskripsi perbandingan pre-test dan post-test pada hasil belajar peserta didik di kelas kontrol dan eksperimen

\begin{tabular}{lcccc}
\hline \multicolumn{1}{c}{ Statistik } & \multicolumn{2}{c}{ Pre-test } & \multicolumn{2}{c}{ Post-test } \\
\cline { 2 - 5 } N & Kontrol & Eksperimen & Kontrol & Eksperimen \\
Tertinggi & 40 & 40 & 40 & 40 \\
Terendah & 48 & 60 & 83 & 88 \\
Rata-rata & 11 & 8 & 34 & 50 \\
\hline
\end{tabular}

Berdasarkan data tersebut, diperoleh peningkatan nilai rata-rata sebesar 30,7 pada kelas kontrol dan 36,6 pada kelas eksperimen. terdapat perbedaan hasil belajar peserta didik yang diajarkan dengan model pembelajaran inkuiri dibandingkan dengan peserta didik yang diajarkan dengan model konvensional [17]. Model pembelajaran inkuiri dapat meningkatkan hasil belajar lebih baik karena memberikan peserta didik kesempatan untuk memecahkan masalah yang ada dengan memanfaatkan lingkungan sekitarnya dalam menemukan jawaban.
Melalui langkah-langkah yang diterapkan dalam model pembelajaran inkuiri, peserta didik mampu memahami materi dengan lebih mudah karena dalam prosesnya melibatkan lingkungan sekitar mereka dan mengajak peserta didik untuk melakukan kegiatan-kegiatan fisik yang membuat suasana belajar lebih menarik. Penggunaan model pembelajaran inkuiri memberikan kesempatan bekerja secara mandiri untuk menemukan sesuatu yang baru karena pada pembelajaran inkuiri ditekankan belajar penemuan dengan peran guru sebagai pendamping dan tidak berperan secara 
langsung sebagai nara sumber dalam pengumpulan fakta, menyusun hipotesis dan penarikan kesimpulan, siswa membangun pengetahuan mereka sendiri [16].

Model pembelajaran inkuiri memberikan pengaruh positif pada pembelajaran peserta didik karena dalam prosesnya peserta didik diajak untuk bekerja seperti seorang imluwan, memberikan peserta didik pengalaman-pengalaman ilmiah, membuat peserta didik lebih mudah memahami materi dan dapat meningkatkan hasil belajar peserta didik [10][20]. Penelitian lainnya menyatakan bahwa model pembelajaran inkuiri memfokuskan peserta didik pada pertanyaan-pertanyaan dan memberikan peserta didik kesempatan untuk menyelidiki jawaban-jawaban yang telah mereka temukan melalui serangkaian percobaan yang dilakukan sendiri oleh peserta didik [13].

Adanya pengalaman langsung dalam pembelajaran membuat peserta didik dapat memproses informasi secara lebih mendalam dan tertata dalam struktur kognitif mereka secara lebih bermakna melalui suatu proses yang bersifat konstruktivis dalam langkah-langkah model pembelajaran inkuiri [6]. Penerapan model pembelajaran inkuiri memberikan peserta didik keberanian dan kebebasan dalam bertanya dan mengembangkan jawaban berdasarkan data yang diperolehnya. Pertanyaan yang diajukan peserta didik dapat dibuktikan langsung melalui penyelidikan oleh peserta didik tersebut sehingga tidak lagi mengandalkan jawaban dari pendidik. Pembelajaran dengan inkuiri mampu meningkatkan rasa penasaran dan ingin tahu peserta didik, sehingga dapat menginspirasi peserta didik untuk menyelidiki dan mencari jawaban permasalahan, serta membantu peserta didik untuk meningkatkan kemampuan berpikir kritis dan kemampuan berkomunikasi peserta didik [15].

Penerapan inkuiri juga memiliki kekurangan dalam pelaksanaannya. Hal ini dapat disebabkan oleh beberapa hal, diantaranya yaitu jumlah peserta didik yang banyak dan peserta didik yang belum terbiasa dengan langkah-langkah model inkuiri. Kelas eksperimen dan kelas kontrol pada penelitian ini, memiliki jumlah peserta didik yang banyak yaitu mencapai 40 orang dalam satu kelas. Hal ini menyebabkan tidak semua peserta didik mampu menerapkan proses inkuiri secara baik. Permasalahan tersebut dapat disebabkan karena peserta didik belum terbiasa dengan pembelajaran mandiri yang ditekankan pada model pembelajaran inkuiri.

Hal tersebut menyebabkan pada tahap awal pembelajaran dengan model inkuiri, peserta didik masih bingung dalam menyusun rumusan masalah, membuat hipotesis dan mengolah informasi. Penerapan model inkuiri bisa saja tidak memberikan pengaruh yang besar pada hasil belajar peserta didik karena peserta didik belum terbiasa dengan aktivitas-aktivitas seperti mengidentifikasi masalah, membuat hipotesis, mengumpulkan informasi, mengolah dan membuktikan hipotesis, serta membuat kesimpulan [10]. Penggunaan inkuiri harus dilakukan dengan lebih sering dan jangka waktu yang lebih panjang. Penggunaan inkuiri dalam jangka waktu yang lebih lama dan sering akan menyebabkan peserta didik lebih nyaman dengan prosedur yang ada dan akan lebih termotivasi serta terlibat dalam pembelajaran [14]

Selain itu, kondisi lingkungan sekolah pada tahap akhir pengambilan data juga mempengaruhi hasil belajar peserta didik. Hal tersebut dikarenakan peserta didik harus belajar di lapangan sekolah dan dengan waktu yang dikurangi dari waktu pembelajaran yang normal yaitu hanya 25 menit untuk setiap jam pembelajaran dari 40 menit waktu normal. Peserta didik juga harus menyesuaikan diri dengan suara-suara dari kelas lain yang duduk berdekatan sehingga membuat konsentrasi peserta didik menjadi terganggu. Hal ini menyebabkan penerapan model pembelajaran inkuiri menjadi kurang optimal.

\section{KESIMPULAN}

Hasil penelitian menunjukkan bahwa, penerapan model pembelajaran inkuiri berpengaruh signifikan terhadap hasil belajar tentang sistem gerak pada peserta didik kelas VIII di SMP Negeri 1 Mataram tahun 2018. Model pembelajaran inkuiri dapat digunakan bagi pendidik dalam memilih model pembelajaran yang akan digunakan dalam pembelajaran materi sistem gerak, karena model pembelajaran inkuiri dapat meningkatkan hasil belajar peserta didik. Dalam penerapan model pembelajaran inkuiri harus memperhatikan alokasi waktu dan kondisi peserta didik sehingga diperoleh hasil yang optimal. Langkah-langkah dalam inkuiri juga harus diajarkan secara perlahan pada peserta didik sehingga peserta didik dapat terbiasa untuk mencari informasi secara mandiri.

\section{DAFTAR PUSTAKA}

[1] Gulo, W. (2008). Strategi Belajar Mengajar. Jakarta: Grasindo.

[2] Eggen, P., \& Kauchak, D. (2012). Strategies and Models for Teachers: Teaching Content and Thinking Skills Sixth Edition. Boston: Pearson Education, Inc.

[3] Sudjana, N. (2002). Dasar-Dasar Proses Belajar Mengajar. Bandung: Sinar Baru Algesindo.

[4] Jufri, A. W. (2013). Belajar dan Pembelajaran SAINS. Bandung: Pustaka Reka Cipta.

[5] Harahap, A. R., \& Sinuraya, J. (2014). Pengaruh Model Pembelajaran Inkuiri Terhadap Hasil Belajar Siswa pada Materi Pokok Listrik Dinamis di Kelas X SMA 
Swasta Al Ulum Medan T.P 2013/2014. Jurnal Inpafi Vol. 2 No.3.

[6] Aini, K., \& Dwiningsih, K. (2014). Penerapan Model Pembelajaran Inkuiri dengan Hands On Minds On Activity untuk Meningkatkan Hasil Belajar Siswa pada Materi Pokok Termokimia. UNESA Journal of Chemical Education Vol. 3 No.1, 99-105.

[7] Hartana, I. A., Suarni, K., \& Candiasa, M. (2014). Pengaruh Model Pembelajaran Inkuiri Terhadap Hasil Belajar TIK Ditinjau dari Motivasi Berprestasi pada Siswa Kelas VIII SMP Ganesha Denpasar. e-Journal Program Pascasarjana Universitas Pendidikan Ganesha Vol.4 Tahun 2014.

[8] Anggareni, N., Ristiati, N., \& Widiyanti, N. (2013). Implementasi Strategi Pembelajaran Inkuiri Terhadap Kemampuan Berpikir Kritis dan Pemahaman Konsep IPA Siswa SMP. $e$ Journal Program Pascasarjana Universitas Pendidikan Ganesha Vol. 3 Tahun 2013.

[9] Juniati, N. W., \& Widiana, I. W. (2017). Penerapan Model Pembelajaran Inkuiri untuk Meningkatkan Hasil Belajar IPA. Jurnal Ilmiah Sekolah Dasar Vol. 1 (1), 20-29.

[10] Setiawan, B., Sunarti, T., \& Astriani, D. (2016). The Applicatiion of Inquiry Learning Model to Improve "Satu Atap" Student's Learning Result at SMPN 4 Singosari Malang. Jurnal Pendidikan IPA Indonesia, 45-50.

[11] Agustanti, T. H. (2012). Implementasi Metode Inquiry untuk Meningkatkan Hasil Belajar Biologi. Jurnal Pendidikan IPA Indonesia 1 (1), 16-20.

[12] Pratiwi, E. (2016). Pengaruh Metode Pembelajaran Inkuiri Terhadap Prestasi Belajar Siswa Kelas IV pada Mata Pelajaran
PKN. Jurnal Pendidikan Guru Sekolah Dasar, 2732-2740.

[13] Supasorn, S., \& Lordkam, A. (2014). Enhancement of Grade 7 Student's Learning Achievement of the Matter Separation by Using Inquiry Learning Activities. Procedia - Social and Behavioral Science, 739-743.

[14] Johnson, S. A., \& Cuevas, J. (2016). The Effects of Inquiry Project Based Learning on Student Reading Motivation and Student Perceptions of Inquiry Learning Processes. Georgia Educational Researcher Vol. 13, 5185.

[15] Widiyastuti, L. O., Prayitno, B. A., \& Ashadi. (2017). The Implementary of Inquiry Learning in Middle School in Masaran. Pancaran Pendidikan FKIP Universitas Jember, 65-72.

[16] Magdalena, O., Mulyani, S., \& VH, E. S. (2014). Pengaruh Pembelajaran Model Problem Based Learning dan Inquiry Terhadap Prestasi Belajar Siswa Ditinjau dari Kreativitas Verbal pada Materi Hukum Dasar Kimia Kelas X SMAN 1 Boyolali Tahun Pelajaran 2013/2014. Jurnal Pendidikan Kimia Vol. 3 No.4, 162-169.

[17] Ramdani, A. (2013). Pembelajaran IPA Biologi Berbasis Inkuiri dengan Lesson Study Meningkatkan Hasil Belajar Siswa. Jurnal Pendidikan Biologi Vol.4 No.2.

[18] Qomaliyah, E. N., Sukib, S., \& Loka, I. N. (2017). Pengaruh model pembelajaran inkuiri terbimbing berbasis literasi sains terhadap hasil belajar materi pokok larutan penyangga. Jurnal Pijar Mipa, 11(2). 